\title{
Displacement of weakly coordinating anions from zirconocene alkyl cations by trialkyl phosphines: A model for olefin coordination in homogeneous Ziegler-Natta catalysis ${ }^{1}$
}

\author{
Stefan Beck, Marc-Heinrich Prosenc, Hans-Herbert Brintzinger * \\ Fakultät für Chemie, Universität Konstanz, D-78343 Konstanz, Germany
}

\begin{abstract}
Displacement of the anion $\mathrm{H}_{3} \mathrm{C}-\mathrm{B}\left(\mathrm{C}_{6} \mathrm{~F}_{5}\right)_{3}^{-}$from the zirconocene contact-ion pair $\left[\left(\mathrm{C}_{5} \mathrm{H}_{5}\right)_{2} \mathrm{Zr}\left(\mathrm{CH}_{3}\right)^{+} \cdots\left(\mu-\mathrm{H}_{3} \mathrm{C}\right)_{-}\right.$ $\mathrm{B}\left(\mathrm{C}_{6} \mathrm{~F}_{5}\right)_{3}^{-}$by a series of phosphines and formation of a bisphosphine complex by uptake of a second phosphine ligand have been studied by NMR methods in $\mathrm{C}_{6} \mathrm{D}_{6}$ solutions. Evidence is presented that associated, outer-sphere ion pairs $\left[\left(\mathrm{C}_{5} \mathrm{H}_{5}\right)_{2} \mathrm{Zr}\left(\mathrm{CH}_{3}\right)\left(\mathrm{PR}_{3}\right)\right]^{+} \mathrm{H}_{3} \mathrm{C}-\mathrm{B}\left(\mathrm{C}_{6} \mathrm{~F}_{5}\right)_{3}^{-}$predominate at zirconocene concentrations up to ca. $2 \mathrm{mM}$; higher aggregates become apparent at higher zirconocene concentrations. Equilibrium constants for the formation of mono- and bis- $\mathrm{PMe}_{3}$ complexes have been determined; the latter are found to be highly sensitive to steric perturbations. These data, together with density-functional estimates for reaction enthalpies, lead to the following qualitative conclusions with regard to olefin coordination in zirconocene-based polymerization catalysts: (i) The olefin substrate displaces the borate anion only from a small equilibrium fraction of the zirconocene alkyl cations present; (ii) the predominant fraction of the resulting zirconocene alkyl olefin cation remains in an outer-sphere association with the counteranion; (iii) mutual displacement of olefin and counteranion from the $\mathrm{Zr}$ center is slow compared to typical olefin insertions; (iv) uptake of a second olefin under formation of a cationic zirconocene alkyl diolefin complex is rather unlikely even at elevated olefin concentrations.
\end{abstract}

\section{Introduction}

Weakly coordinating anions and their interactions with organometallic cations [1,2] play a prominent role in homogeneous polymerization catalysis: Coordination of an olefin to the $\mathrm{Zr}$ center of a cationic zirconocene alkyl complex, a prerequisite for zirconocene-catalyzed olefin polymerization, is generally assumed to proceed

\footnotetext{
* Corresponding author. Fax: +49-7531-883137; e-mail: hans.brintzinger@uni-konstanz.de

${ }^{1}$ Dedicated to Professor Wolfgang Beck on the occasion of his 65 th birthday.
}

via reversible displacement of a weakly coordinating anion $\mathrm{A}^{-}$by the olefin substrate [3-5] (Eq. (1)). Depending on the activating reagent, $\mathrm{A}^{-}$can stand for

- a borate anion such as $\mathrm{B}\left(\mathrm{C}_{6} \mathrm{~F}_{5}\right)_{4}^{-}$(introduced by reaction of its triorganyl ammonium or triphenyl carbenium salt with a dimethyl zirconocene [6-9]),

- for a methyl borate anion $\mathrm{H}_{3} \mathrm{C}-\mathrm{B}\left(\mathrm{C}_{6} \mathrm{~F}_{5}\right)_{3}^{-}$ (generated by abstraction of $\mathrm{CH}_{3}^{-}$from the $\mathrm{Zr}$ center by the Lewis-acidic activator $\left.\mathrm{B}\left(\mathrm{C}_{6} \mathrm{~F}_{5}\right)_{3}\right)$ [10a,10b,11-13]), or

- for a complex anion $\mathrm{H}_{3} \mathrm{C}-\mathrm{MAO}^{-}$or $\mathrm{Cl}-$ $\mathrm{MAO}^{-}$(formed in a similar manner by a 
Lewis-acidic $\mathrm{Al}$ center present in methyl aluminoxane (MAO) $[14,15]$ ).

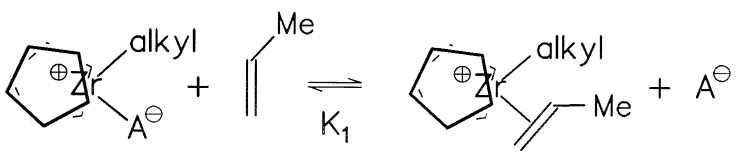

To understand how activities and other properties of zirconocene catalysts are affected by a particular activator reagent, it appears necessary to clarify the thermodynamics and kinetics of this basic preequilibrium. While it is generally assumed, based on the increase of catalytic activities with monomer concentration, that this equilibrium lies predominantly on the left side under typical reaction conditions, it is not clear how it is affected by changing zirconocene structures. Another unsolved question concerns the relative concentrations of solvent-separated and of associated ion pairs (Eq. (2)) and their respective contributions to the overall activity of a given catalyst system [4]. In addition, it has been suggested [16-18] that coordination of a second olefin to the $\mathrm{Zr}$ center might be required for efficient olefin insertion (Eq. (3)). The occurance of five-coordinate zirconocene alkyl olefin complexes in equilibria such as Eqs. (2) and (3) rests on rather indirect kinetic evidence, however.
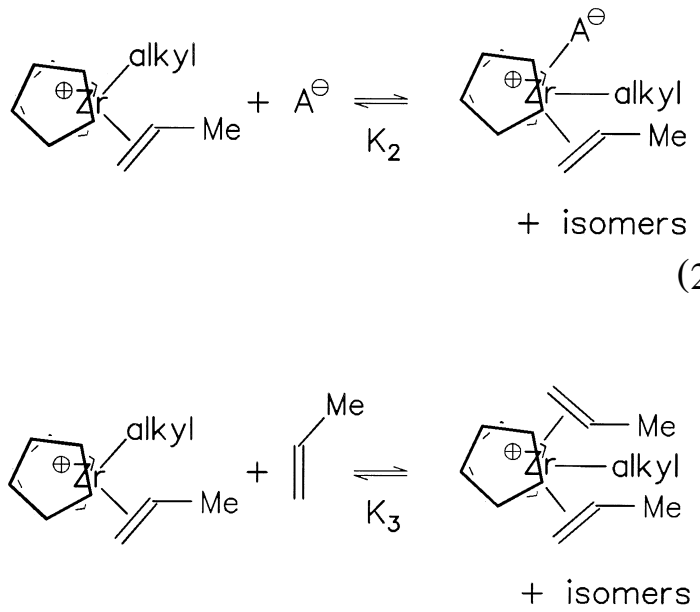

In a few special cases, where an olefin ligand is tethered to a d $\mathrm{d}^{0}$-configurated metal center by an alkyl or alkoxy chain, olefin adducts of the type represented in Eq. (1) have been characterized with regard to their stabilities and structures by NMR spectroscopy and X-ray diffractometry $[19,20]$. In active zirconocene catalyst systems however, olefin complexes have remained spectroscopically undetectable, as the high propensity of these species to undergo olefin insertion will necessarily keep their steady-state concentration very low.

In order to gain at least qualitative insights into the characteristics of olefin coordination to zirconocene cations, reaction systems in which the olefin substrate is replaced by a trialkyl phosphine ligand have been proposed by Jordan and coworkers as models for olefin coordination in homogeneous polymerization catalysts [2123]. In these studies it was shown that a trialkyl phosphine can coordinate to a zirconocene alkyl cation under replacement of the counter-anion and that complexes containing two phosphine ligands are formed at higher phosphine concentrations. Here, we report results of a quantitative study on the corresponding complex formation equilibria, which might eventually allow conclusions also with regard to the elusive olefin coordination equilibria represented in Eqs. (1) (3).

\section{Results and discussion}

For the following studies, we have primarily utilized the reaction system $\left(\mathrm{C}_{5} \mathrm{H}_{5}\right)_{2} \mathrm{Zr}$ $\left(\mathrm{CH}_{3}\right)_{2} / \mathrm{B}\left(\mathrm{C}_{6} \mathrm{~F}_{5}\right)_{3}$ in $\mathrm{C}_{6} \mathrm{D}_{6}$ solution $[10 \mathrm{a}, 10 \mathrm{~b}$, 11-13]. The ${ }^{1} \mathrm{H}$-NMR shift of the anion $\mathrm{H}_{3} \mathrm{C}-$ $\mathrm{B}\left(\mathrm{C}_{6} \mathrm{~F}_{5}\right)_{3}^{-}$represents a sensitive probe for the identity of the species present [24,25] and the relative concentrations of the reaction participants are easily determined by ${ }^{1} \mathrm{H}-\mathrm{NMR}$ (see Section 4).

When a sufficiently dilute solution $\left([\mathrm{Zr}]_{\mathrm{tot}} \leq 2\right.$ $\mathrm{mM})$ of the contact ion pair $\left[\left(\mathrm{C}_{5} \mathrm{H}_{5}\right)_{2} \mathrm{Zr}\left(\mathrm{CH}_{3}\right)^{+}\right.$ $\left.\cdots\left(\mu-\mathrm{H}_{3} \mathrm{C}\right)-\mathrm{B}\left(\mathrm{C}_{6} \mathrm{~F}_{5}\right)_{3}^{-}\right]$is treated with slightly 
less than one equivalent of a typical trialkyl or triaryl phospine, one observes the immediate and complete formation of a signal set assignable to a cationic monophosphine complex $\left[\left(\mathrm{C}_{5} \mathrm{H}_{5}\right)_{2} \mathrm{Zr}\left(\mathrm{CH}_{3}\right)\left(\mathrm{PR}_{3}\right)\right]^{+}$and 'free' anion $\mathrm{H}_{3} \mathrm{C}-\mathrm{B}\left(\mathrm{C}_{6} \mathrm{~F}_{5}\right)_{3}^{-}$with a broad ${ }^{1} \mathrm{H}-\mathrm{NMR}$ signal at 1.3-1.4 ppm (Table 1). Analogous studies on reaction systems at higher zirconocene concentrations ( $\left.[\mathrm{Zr}]_{\text {tot }}>4 \mathrm{mmol}\right)$ reveal, in addition to the species just described, increasing fractions of another monophosphine complex of the same composition; the $\mathrm{H}_{3} \mathrm{~B}-\left(\mathrm{C}_{6} \mathrm{~F}_{5}\right)_{3}^{-}$anion of this species gives rise to a ${ }^{1} \mathrm{H}-\mathrm{NMR}$ signal at $1.0-1.1$ ppm (Fig. 1, Table 1). The disappearance of this species upon dilution of the reaction mixture with $\mathrm{C}_{6} \mathrm{D}_{6}$ documents that the two alternative monophosphine complexes coexist in a reversible, concentration-dependent equilibrium with each other.
In analogy to an interpretation of related observations with binuclear alkyl zirconocene cations [24,25], we had initially assumed, that a solvent-separated and an associated ion pair would be present in a concentration-dependent equilibrium. Several observations, especially with regard to the rates of mutual interconversion reactions, are not consistent with this assumption, however: Exchange signals in the NOESY spectrum, which interconnect the ${ }^{1} \mathrm{H}-$ NMR signals of the contact-ion pair $\left[\left(\mathrm{C}_{5} \mathrm{H}_{5}\right)_{2} \mathrm{Zr}\left(\mathrm{CH}_{3}\right)^{+} \cdots\left(\mu-\mathrm{H}_{3} \mathrm{C}\right)-\mathrm{B}\left(\mathrm{C}_{6} \mathrm{~F}_{5}\right)_{3}^{-}\right]$ with the corresponding signals of the phosphine complex $\left[\left(\mathrm{C}_{5} \mathrm{H}_{5}\right)_{2} \mathrm{Zr}\left(\mathrm{CH}_{3}\right)\left(\mathrm{PR}_{3}\right)\right]^{+} \mathrm{H}_{3} \mathrm{C}-$ $\mathrm{B}\left(\mathrm{C}_{6} \mathrm{~F}_{5}\right)_{3}^{-}$apparent in dilute solution, indicate a half-live of ca. 5-10 s for the interchange between these two species. Neither of these species gives rise to any detectable cross signals, however, with the monophosphine complex favored

Table 1

${ }^{1} \mathrm{H}-\mathrm{NMR}$ signals of the associated zirconocene phosphine complexes $\left[\mathrm{Cp}_{2} \mathrm{ZrMe}\left(\mathrm{PR}_{3}\right)^{+}, \mathrm{MeB}\left(\mathrm{C}_{6} \mathrm{~F}_{5}\right)_{3}^{-}\right]$(assoc.) and of the corresponding aggregated complexes $\left[\mathrm{Cp}_{2} \mathrm{ZrMe}\left(\mathrm{PR}_{3}\right)^{+}, \mathrm{MeB}\left(\mathrm{C}_{6} \mathrm{~F}_{5}\right)_{3}^{-}\right]_{n}$ (aggr.), in $\mathrm{C}_{6} \mathrm{D}_{6}$ at $30^{\circ} \mathrm{C}$

\begin{tabular}{|c|c|c|c|c|}
\hline $\mathrm{PR}_{3}$ & $\delta\left(\mathrm{C}_{5} \mathrm{H}_{5}\right)$ & $\delta\left(\mathrm{Zr}-\mathrm{CH}_{3}\right)$ & $\delta(\mathrm{P}-\mathrm{R})$ & $\delta\left(\mathrm{H}_{3} \mathrm{C}-\mathrm{B}\left(\mathrm{C}_{6} \mathrm{~F}_{5}\right)_{3}^{-}\right)$ \\
\hline \multicolumn{5}{|l|}{$\mathrm{PMe}_{3}$} \\
\hline assoc. & $5.50(10, \mathrm{~d}, 2.5 \mathrm{~Hz})$ & $-0.20(3, \mathrm{~s})$ & $\mathrm{CH}_{3}: 0.30(9, \mathrm{~d}, 8.4 \mathrm{~Hz})$ & $1.4(3, \mathrm{br})$ \\
\hline aggr. & $5.47(10, \mathrm{~s})$ & $-0.22(3, \mathrm{~s})$ & $\mathrm{CH}_{3}: 0.28(6, \mathrm{~d}, 8 \mathrm{~Hz})$ & $1.0(3, \mathrm{br})$ \\
\hline \multicolumn{5}{|l|}{$\mathrm{PMe}_{2} \mathrm{Ph}$} \\
\hline assoc. & $5.50(10, \mathrm{~d}, 1.6 \mathrm{~Hz})$ & $-0.14(3, \mathrm{~d}, 2.6 \mathrm{~Hz})$ & $\mathrm{CH}_{3}: 0.68(6, \mathrm{~d}, 8.0 \mathrm{~Hz})$ & $1.4(3, \mathrm{br})$ \\
\hline aggr. & $5.43(10, \mathrm{~d}, 1.6 \mathrm{~Hz})$ & $-0.18(3, \mathrm{~s})$ & $\mathrm{CH}_{3}: 0.60(6, \mathrm{~d}, 7.9 \mathrm{~Hz})$ & $1.1(3, \mathrm{br})$ \\
\hline \multicolumn{5}{|l|}{$\mathrm{PEt}_{3}$} \\
\hline assoc. & $5.55(10, \mathrm{~d}, 1.1 \mathrm{~Hz})$ & $-0.22(3, \mathrm{~s})$ & $\begin{array}{l}\mathrm{CH}_{2}: 1.28--1.20(6, \mathrm{~m}) \\
\mathrm{CH}_{3}: 0.34-0.28(9, \mathrm{~m})\end{array}$ & $1.4(3, \mathrm{br})$ \\
\hline aggr. & $5.50(10, \mathrm{~d}, 0.9 \mathrm{~Hz})$ & $-0.18(3, \mathrm{~s})$ & $\mathrm{CH}_{3}: 0.27-0.18(6, \mathrm{~d}, 7.9 \mathrm{~Hz})$ & $1.0(3, \mathrm{br})$ \\
\hline \multicolumn{5}{|l|}{$\mathrm{P}\left({ }^{n} \mathrm{Bu}\right)_{3}$} \\
\hline assoc. & $5.66(10, \mathrm{~d}, 1.0 \mathrm{~Hz})$ & $-0.11(3, \mathrm{~s})$ & not resolved & $1.4(3, \mathrm{br})$ \\
\hline aggr. & $5.60(10, \mathrm{~s})$ & $-0.16(3, \mathrm{~s})$ & not resolved & not resolved \\
\hline \multicolumn{5}{|l|}{$\mathrm{PMePh}_{2}$} \\
\hline assoc. & $5.59(10, \mathrm{~d}, 1.1 \mathrm{~Hz})$ & $0.04(3, \mathrm{~s})$ & $\mathrm{CH}_{3}: 1.05(3, \mathrm{~d}, 7.3 \mathrm{~Hz})$ & $1.4(3, \mathrm{br})$ \\
\hline aggr. & $5.48(10, \mathrm{~d}, 1.0 \mathrm{~Hz})$ & $-0.02(3, \mathrm{~s})$ & $\mathrm{CH}_{3}: 0.97(3, \mathrm{~d}, 7.3 \mathrm{~Hz})$ & $1.1(3, \mathrm{br})$ \\
\hline \multicolumn{5}{|l|}{$\mathrm{PPh}_{3}$} \\
\hline assoc. & $5.64(10, \mathrm{~d}, 1.1 \mathrm{~Hz})$ & $0.27(3, \mathrm{~s})$ & not resolved & $1.4(3, \mathrm{br})$ \\
\hline aggr. & $5.50(10, \mathrm{~d}, 1.0 \mathrm{~Hz})$ & $0.19(3, \mathrm{~s})$ & not resolved & $1.1(3, \mathrm{br})$ \\
\hline \multicolumn{5}{|c|}{$\mathrm{P}\left[(p-\mathrm{MeO}) \mathrm{C}_{6} \mathrm{H}_{4}\right]_{3}$} \\
\hline assoc. & $5.71(10, \mathrm{~d}, 1.1 \mathrm{~Hz})$ & $0.33(3, \mathrm{~s})$ & $-\mathrm{OCH}_{3}: 3.32(9, \mathrm{~s})$ & $1.4(3, \mathrm{br})$ \\
\hline aggr. & $5.60(10, s)$ & $0.24(3, \mathrm{~s})$ & $-\mathrm{OCH}_{3}: 3.23(9, \mathrm{~s})$ & $1.0(3, \mathrm{br})$ \\
\hline \multicolumn{5}{|l|}{$\mathrm{P}(\mathrm{Bn})_{3}$} \\
\hline assoc. & $5.46(10, \mathrm{~d}, 1.0 \mathrm{~Hz})$ & $-0.09(3, \mathrm{~s})$ & $\mathrm{CH}_{2}: 2.59(6, \mathrm{~d}, 6.8 \mathrm{~Hz})$ & $1.4(3, \mathrm{br})$ \\
\hline aggr. & $5.34(10, \mathrm{~s})$ & $-0.18(3$, br $)$ & $\mathrm{CH}_{2}: 2.45(6, \mathrm{~d}, 6.4 \mathrm{~Hz})$ & $1.1(3, \mathrm{br})$ \\
\hline \multicolumn{5}{|l|}{$\mathrm{P}(\mathrm{Cy})_{3}$} \\
\hline assoc. & $5.75(10, \mathrm{~d}, 0.8 \mathrm{~Hz})$ & $0.01(3, \mathrm{~s})$ & not resolved & not resolved \\
\hline aggr. & $5.62(10, \mathrm{~s})$ & $-0.08(3, \mathrm{~s})$ & not resolved & not resolved \\
\hline
\end{tabular}




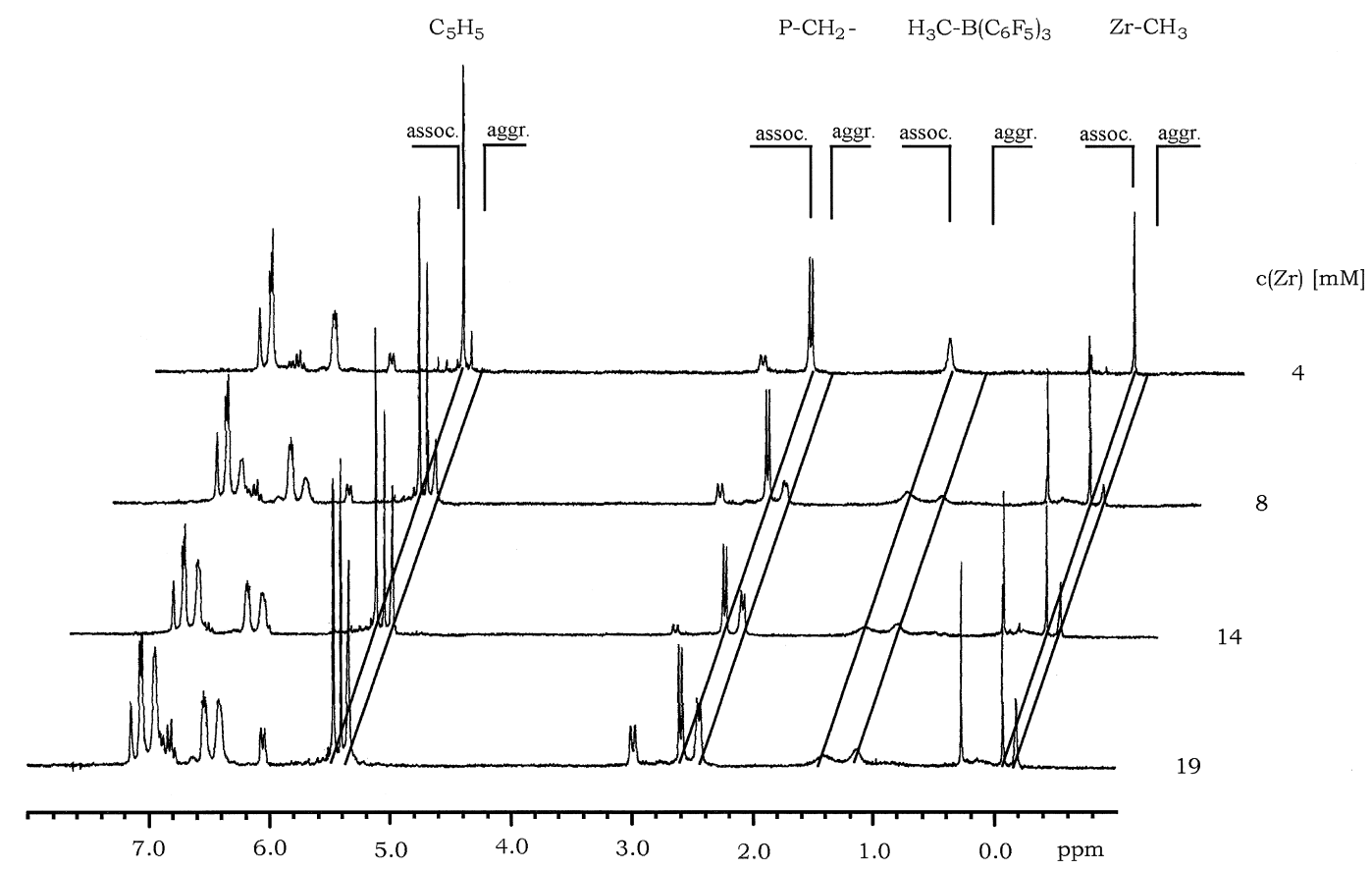

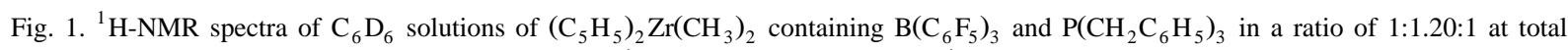
zirconocene concentrations ranging from 4 to $19 \mathrm{mM}$ (room temperature, $250 \mathrm{MHz}$ ).

by higher zirconocene concentrations. This sets a lower limit of ca. $1 \mathrm{~min}$ for the half-live of the interconversion between the two monophosphine species. The absence of any intensity changes after the first NMR measurement of a solution, on the other hand, ca. 10-15 min after its preparation or dilution, sets an upper half-live limit of 2-3 min for this interconversion.

Such a low rate of interconversion appears incompatible with an equilibrium involving a simple interchange between solvent-separated and associated ion pairs of the type considered here: It is not apparent which kind of reaction barrier could make this subtle interconversion slower, by about one order of magnitude, than the mutual displacement of $\mathrm{PR}_{3}$ and $\mathrm{H}_{3} \mathrm{C}-$ $\mathrm{B}\left(\mathrm{C}_{6} \mathrm{~F}_{5}\right)_{3}^{-}$from the $\mathrm{Zr}$ center. As a more plausible alternative, we assume that the phosphine complex favored by higher zirconocene concentrations is a more highly aggregated form, possibly a colloidal microphase, formed by the ion pair $\left[\left(\mathrm{C}_{5} \mathrm{H}_{5}\right)_{2} \mathrm{Zr}\left(\mathrm{CH}_{3}\right)\left(\mathrm{PR}_{3}\right)\right]^{+} \mathrm{H}_{3} \mathrm{C}-\mathrm{B}\left(\mathrm{C}_{6} \mathrm{~F}_{5}\right)_{3}^{-}$ in benzene solution [26]. For aggregates of this type one might expect a reduced rate of interchange with the monodisperse species. This assignment is supported by the observation that the phosphine-complex ion pair is slowly lost from these solutions, in form of an oily deposit, whenever the total zirconocene concentration is high enough to lead to formation of appreciable fractions of the aggregated form of this complex. The intensity of the signal assigned to the aggregated form appears to correlate with the amount of finely dispersed oily phase in the measuring region of the NMR tube in the spectrometer.

In more dilute benzene solutions the cationic phosphine complex is undoubtedly present in an associated ion pair $\left[\left(\mathrm{C}_{5} \mathrm{H}_{5}\right)_{2} \mathrm{Zr}\right.$ $\left.\left(\mathrm{CH}_{3}\right)\left(\mathrm{PMe}_{3}\right)\right]^{+} \mathrm{H}_{3} \mathrm{C}-\mathrm{B}\left(\mathrm{C}_{6} \mathrm{~F}_{5}\right)_{3}^{-}$: The Coulomb energy required to separate such an ion pair into its constituent ions can be estimated to amount to ca. $80-100 \mathrm{~kJ} / \mathrm{mol}$ in benzene solution. Based on the models developed by Fuoss [26], the association constant for ion pairs of this type, with a distance of 7-8 $\AA$ between the $\mathrm{Zr}^{+}$ 

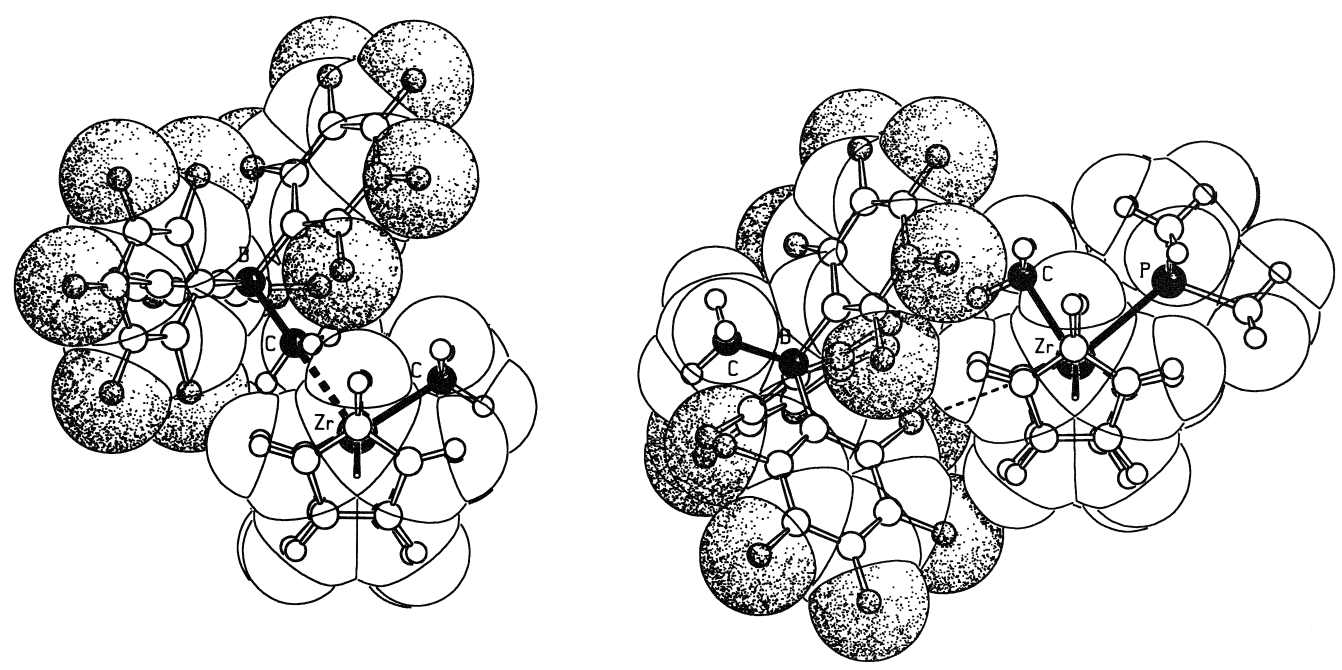

Fig. 2. Models of a contact ion pair $\left[\left(\mathrm{C}_{5} \mathrm{H}_{5}\right)_{2} \mathrm{Zr}\left(\mathrm{CH}_{3}\right)^{+} \cdots\left(\mu-\mathrm{H}_{3} \mathrm{C}\right)-\mathrm{B}\left(\mathrm{C}_{6} \mathrm{~F}_{5}\right)_{3}^{-}\right]$(left) and of an outer-sphere complex ion pair $\left[\left(\mathrm{C}_{5} \mathrm{H}_{5}\right)_{2} \mathrm{Zr}\left(\mathrm{CH}_{3}\right)\left(\mathrm{PMe}_{3}\right)\right]^{+} \mathrm{H}_{3} \mathrm{C}-\mathrm{B}\left(\mathrm{C}_{6} \mathrm{~F}_{5}\right)_{3}^{-}$(right) derived from density-functional geometry optimizations (SCHAKAL graphics).

and $\mathrm{B}^{-}$charge centers, is estimated to have a value in the range of $K_{\text {ass }} \approx 10^{7}-10^{9}$.

Possible structures of such an associated ion pair have been analyzed by density-functional model calculations (Section 4). A direct contact of the anion $\mathrm{H}_{3} \mathrm{C}-\mathrm{B}\left(\mathrm{C}_{6} \mathrm{~F}_{5}\right)_{3}^{-}$with the zirconocene cation via the $\mathrm{H}_{3} \mathrm{C}$-group, observed for contact ion pairs of the type $\left[\left(\mathrm{C}_{5}\right.\right.$ $\left.\left.\mathrm{H}_{5}\right)_{2} \mathrm{Zr}\left(\mathrm{CH}_{3}\right)^{+} \cdots\left(\mu-\mathrm{H}_{3} \mathrm{C}\right)-\mathrm{B}\left(\mathrm{C}_{6} \mathrm{~F}_{5}\right)_{3}^{-}\right]$ $[12,13,25,27]$, is nicely reproduced, with $\mathrm{Zr}$ $\mathrm{CH}_{3}$ and $\mathrm{Zr}-\mu-\mathrm{CH}_{3}$ distances of 2.27 and 2.47 $\AA$, by a density-functional geometry optimization (Fig. 2). A geometry optimization for a $\mathrm{CH}_{3}$-bridged contact ion pair $\left[\left(\mathrm{C}_{5} \mathrm{H}_{5}\right)_{2}\right.$ $\left.\mathrm{Zr}\left(\mathrm{CH}_{3}\right)\left(\mathrm{PMe}_{3}\right)^{+} \ldots\left(\mu-\mathrm{H}_{3} \mathrm{C}\right)-\mathrm{B}\left(\mathrm{C}_{6} \mathrm{~F}_{5}\right)_{3}^{-}\right]$, however, leads to an energy minimum at a much too large $\mathrm{Zr}-\mu-\mathrm{CH}_{3}$ distance of ca. $5 \AA$, probably due to steric overcrowding.

We consider it most likely, therefore, that the ions $\left[\left(\mathrm{C}_{5} \mathrm{H}_{5}\right)_{2} \mathrm{Zr}\left(\mathrm{CH}_{3}\right)\left(\mathrm{PMe}_{3}\right)\right]^{+}$and $\mathrm{H}_{3} \mathrm{C}-$ $\mathrm{B}\left(\mathrm{C}_{6} \mathrm{~F}_{5}\right)_{3}^{-}$remain in contact with each other in a geometrically nondescript outer-sphere coordination: In a large number of solid-state structures, zirconocene cations with 16-electron configuration and their aryl borate counteranions are found to be closely packed, with distances of 6.5-7.5 $\AA$ between their $\mathrm{Zr}^{+}$and $\mathrm{B}^{-}$centers, without direct bonding contacts of any part of the anion to the $\mathrm{Zr}$ center [20,21,28-36]. Density-functional calculations yield for such an outer-sphere associate an optimized geometry with a $\mathrm{Zr}^{+}-\mathrm{B}^{-}$distance of ca. $6.4 \AA$ (Fig. 2). This geometry places one of the fluoro substituents of the arylborate anion at a distance of only $4.0 \AA$ from the $\mathrm{Zr}$ center. Similar $\mathrm{Zr}-\mathrm{F}$ contacts have been observed before in other cases $[28,29]$. Other geometries with somewhat larger $\mathrm{Zr}^{+}-\mathrm{B}^{-}$distances in the range of ca. 7 $\AA$, however, are found at energies which are higher by only a few $\mathrm{kJ} / \mathrm{mol}$. It is apparent that the mutual arrangement of cation and anion in such an ion pair is largely accidental and will depend, inter alia, on the substituent pattern of the zirconocene cation.

Such a displacement of the anion $\mathrm{H}_{3} \mathrm{C}-$ $\mathrm{B}\left(\mathrm{C}_{6} \mathrm{~F}_{5}\right)_{3}^{-}$by $\mathrm{PR}_{3}$ from the the inner to the outer coordination sphere of the cation $\left[\left(\mathrm{C}_{5} \mathrm{H}_{5}\right)_{2} \mathrm{Zr}\left(\mathrm{CH}_{3}\right)\right]^{+}$is represented by Eq. (4). Equilibrium constant $K_{4}$ for this reaction cannot be determined directly, since free phosphine is not detectable in reaction systems containing finite amounts of the contact ion pair $\left[\left(\mathrm{C}_{5} \mathrm{H}_{5}\right)_{2} \mathrm{Zr}\left(\mathrm{CH}_{3}\right)^{+} \ldots\left(\mu-\mathrm{H}_{3} \mathrm{C}\right)-\mathrm{B}\left(\mathrm{C}_{6} \mathrm{~F}_{5}\right)_{3}^{-}\right]$. For the case of $\mathrm{PMe}_{3}$, however, further analysis 
allows an estimate of this equilibrium constant (vide infra).

$$
\begin{aligned}
& {\left[\left(\mathrm{C}_{5} \mathrm{H}_{5}\right)_{2} \mathrm{Zr}\left(\mathrm{CH}_{3}\right)^{+} \cdots \mathrm{A}^{-}\right]+\mathrm{PR}_{3}} \\
& \rightleftharpoons\left[\left(\mathrm{C}_{5} \mathrm{H}_{5}\right)_{2} \mathrm{Zr}\left(\mathrm{CH}_{3}\right)\left(\mathrm{PR}_{3}\right)\right]^{+} \mathrm{A}^{-}
\end{aligned}
$$

In an investigation of the equilibrium which leads to five-coordinate complexes with two phosphine ligands, $\left[\left(\mathrm{C}_{5} \mathrm{H}_{5}\right)_{2} \mathrm{Zr}\left(\mathrm{CH}_{3}\right)\left(\mathrm{PR}_{3}\right)_{2}\right]^{+}$, Jordan et al. had observed that addition of excess $\mathrm{PMe}_{3}$ to solutions of $\left[\left(\mathrm{C}_{5} \mathrm{H}_{5}\right)_{2} \mathrm{Zr}\left(\mathrm{CH}_{3}\right)\right.$ $\left.(\mathrm{THF})\left(\mathrm{PMe}_{3}\right)\right]^{+} \mathrm{B}\left(\mathrm{C}_{6} \mathrm{H}_{5}\right)_{4}^{-}$in THF- $d_{8}$ leads to formation of $\left[\left(\mathrm{C}_{5} \mathrm{H}_{5}\right)_{2} \mathrm{Zr}\left(\mathrm{CH}_{3}\right)\left(\mathrm{PMe}_{3}\right)_{2}\right]^{+}$, especially at lower temperatures [21]. In accord with that report, we observe shifts of the $\mathrm{C}_{5} \mathrm{H}_{5}$ and $\mathrm{Zr}-\mathrm{CH}_{3}$ signals when the ion pair $\left[\left(\mathrm{C}_{5}\right.\right.$ $\left.\left.\mathrm{H}_{5}\right)_{2} \mathrm{Zr}-\left(\mathrm{CH}_{3}\right)\left(\mathrm{PMe}_{3}\right)\right]^{+} \mathrm{H}_{3} \mathrm{C}-\mathrm{B}\left(\mathrm{C}_{6} \mathrm{~F}_{5}\right)_{3}^{-}$(pre sent at low zirconocene concentrations) is treated with increasing concentrations of $\mathrm{PMe}_{3}$ (Fig. 3). Limiting shift values of $4.99 \mathrm{ppm}$ and -1.44 ppm, respectively, are reached at $\mathrm{PMe}_{3}$ concentrations above $20 \mathrm{mM}$. From plots of $\left(\delta_{\text {obs }}-\right.$ $\left.\delta_{0}\right)^{-1}$ against $\mathrm{c}\left(\mathrm{PMe}_{3}\right)^{-1}$ [37], we obtain a room-temperature value of $K_{5}=640 \mathrm{~mol} / 1$ for the equilibrium represented in Eq. (5), i.e., for an equilibrium involving associated ion pairs.

$$
\begin{gathered}
{\left[\left(\mathrm{C}_{5} \mathrm{H}_{5}\right)_{2} \mathrm{Zr}\left(\mathrm{CH}_{3}\right)\left(\mathrm{PMe}_{3}\right)\right]^{+} \mathrm{A}^{-}+\mathrm{PR}_{3}} \\
\rightleftharpoons\left[\left(\mathrm{C}_{5} \mathrm{H}_{5}\right)_{2} \mathrm{Zr}\left(\mathrm{CH}_{3}\right)\left(\mathrm{PMe}_{3}\right)_{2}\right]^{+}, \mathrm{A}^{-}
\end{gathered}
$$

To check the influence of the anion $\mathrm{A}^{-}$on this equlibrium, we have studied also the reaction of the ion pair $\left[\left(\mathrm{C}_{5} \mathrm{H}_{5}\right)_{2} \mathrm{Zr}\left(\mathrm{CH}_{3}\right)\right.$ $\left.\left(\mathrm{PMe}_{3}\right)\right]^{+} \mathrm{B}\left(\mathrm{C}_{6} \mathrm{~F}_{5}\right)_{4}^{-}$, generated by reacting $\left(\mathrm{C}_{5} \mathrm{H}_{5}\right)_{2} \mathrm{Zr}\left(\mathrm{CH}_{3}\right)_{2}$ with an equivalent of trityl tetrakis(perfluorophenyl)borate [9] in the presence of excess $\mathrm{PMe}_{3}$. Analysis of the $\mathrm{PMe}_{3}$-induced shifts of the $\mathrm{Zr}-\mathrm{CH}_{3}$ signal, as described above, gave an equilibrium constant $K_{5}=370$ $1 / \mathrm{mol}$. This value differs from that for the analogous reaction system containing the anion $\mathrm{H}_{3} \mathrm{C}-\mathrm{B}\left(\mathrm{C}_{6} \mathrm{~F}_{5}\right)_{3}^{-}$by a factor of about 2. This would support the notion that the anion participates in Eq. (5) directly (rather than as a mere
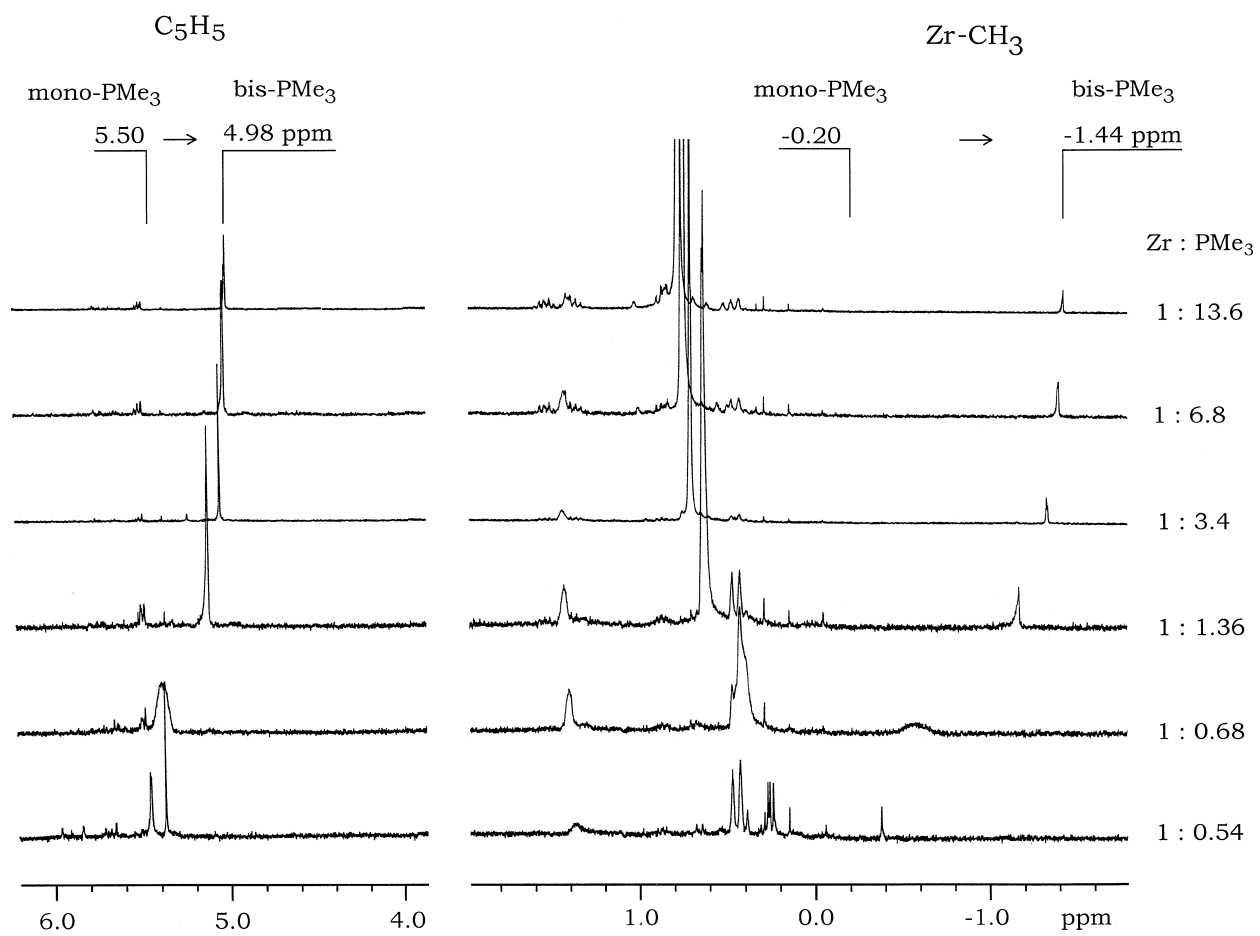

Fig. 3. ${ }^{1} \mathrm{H}-\mathrm{NMR}$ spectra of $1.8 \mathrm{mM}$ solutions of $\left(\mathrm{C}_{5} \mathrm{H}_{5}\right)_{2} \mathrm{Zr}\left(\mathrm{CH}_{3}\right)_{2}$ in $\mathrm{C}_{6} \mathrm{D}_{6}$ containing $\mathrm{B}\left(\mathrm{C}_{6} \mathrm{~F}_{5}\right)_{3}$ in a $\mathrm{B}: \mathrm{Zr}$ ratio of $1.2: 1$ and $\mathrm{PMe}{ }_{3}$ in $\mathrm{P}: \mathrm{Zr}$ ratios ranging from $0.54: 1$ to $13.6: 1$ (conditions as in Fig. 1). 
spectator ion). For the mode of binding of the anion to the cationic bisphosphine complex in the ion pair $\left[\left(\mathrm{C}_{5} \mathrm{H}_{5}\right)_{2} \mathrm{Zr}\left(\mathrm{CH}_{3}\right)\left(\mathrm{PMe}_{3}\right)_{2}\right]^{+} \mathrm{A}^{-}$, a similarly nondescript outer-sphere association as that discussed above for the corresponding monophosphine complex is indicated by the practically identical chemical shifts of the $\mathrm{H}_{3} \mathrm{C}-\mathrm{B}\left(\mathrm{C}_{6} \mathrm{~F}_{5}\right)_{3}^{-}$anion in both complexes.

${ }^{1} \mathrm{H}-\mathrm{NMR}$ data obtained for $\left[\left(\mathrm{C}_{5} \mathrm{H}_{5}\right)_{2}\right.$ $\left.\mathrm{Zr}\left(\mathrm{CH}_{3}\right)\left(\mathrm{PMe}_{3}\right)_{2}\right]^{+}$at a temperature of $-80^{\circ} \mathrm{C}$ in $\mathrm{CD}_{2} \mathrm{Cl}_{2}$, especially a splitting of the $\mathrm{Zr}\left(\mathrm{CH}_{3}\right)$ signal to a $1: 2: 1$ pseudotriplet by coupling to two equivalent $\mathrm{P}$ atoms, indicate a symmetrical structure of this cation, as noted before by Jordan et al. [21]. This assignment is supported by ${ }^{1} \mathrm{H}-\mathrm{NMR}$ data for the dimethylsilyl-bridged complex $\quad\left[\mathrm{Me}_{2} \mathrm{Si}\left(\mathrm{C}_{5} \mathrm{H}_{4}\right)_{2} \mathrm{Zr}\left(\mathrm{CH}_{3}\right)\right.$ $\left.\left(\mathrm{PMe}_{3}\right)_{2}\right]^{+}$, obtained by reaction of $\mathrm{Me}_{2} \mathrm{Si}\left(\mathrm{C}_{5} \mathrm{H}_{4}\right)_{2} \mathrm{Zr}\left(\mathrm{CH}_{3}\right)_{2}$ with one equivalent of $\mathrm{B}\left(\mathrm{C}_{6} \mathrm{~F}_{5}\right)_{3}$ in the presence of excess $\mathrm{PMe}_{3}$ (Table 2): The appearance of only one signal for the $\mathrm{Me}_{2} \mathrm{Si}$ bridge and of two pseudotriplets for the $\mathrm{C}_{5}$-ring protons indicates a $\mathrm{C}_{2 \mathrm{v}}$-symmetric geometry. The stability constant of this complex, $K_{5}=1000 \pm 100 \mathrm{l} / \mathrm{mol}$, is somewhat larger than that of its unbridged congener discussed above, presumably due to a slightly more open geometry of $\mathrm{Me}_{2} \mathrm{Si}\left(\mathrm{C}_{5} \mathrm{H}_{4}\right)_{2} \mathrm{ZrCl}_{2}$ than of $\left(\mathrm{C}_{5} \mathrm{H}_{5}\right)_{2} \mathrm{ZrCl}_{2}$.

These data do not rigorously exclude the possibility, however, that some fraction of the bisphosphine complex is present in form of the unsymmetrical isomer, in which the methyl group is placed in a lateral coordination position, as obseved by Jordan and coworkers for the chelated complex $\left[\left(\mathrm{C}_{5} \mathrm{H}_{5}\right)_{2} \mathrm{Zr}\left(\mathrm{CH}_{3}\right)\right.$ $\left.\left(\mathrm{PMe}_{2}\right)_{2} \mathrm{C}_{2} \mathrm{H}_{4}\right]^{+}$[21]: Exchange between monophosphine and bisphospine complexes according to Eq. (5) is fast on the NMR time scale even at $-40^{\circ} \mathrm{C}$; if this is true also for exchange between different isomers of the bisphosphine complex, their apparent $\mathrm{C}_{2 \mathrm{v}}$ symmetry might merely represent a time-averaged geometry.

For the other phosphines studied, bisphosphine complexes appear to be much less stable. With $20 \mathrm{mM} \mathrm{P}(\mathrm{Et})_{3}$, for example, we observe shifts of only $0.07 \mathrm{ppm}$ for the $\mathrm{Zr}\left(\mathrm{CH}_{3}\right)$ signal of $\left[\left(\mathrm{C}_{5} \mathrm{H}_{5}\right)_{2} \mathrm{Zr}\left(\mathrm{CH}_{3}\right)\left(\mathrm{PEt}_{3}\right)\right]^{+}$. If we assume a similar limiting shift value for this signal as for that in $\left[\left(\mathrm{C}_{5} \mathrm{H}_{5}\right)_{2} \mathrm{Zr}\left(\mathrm{CH}_{3}\right)\left(\mathrm{PMe}_{3}\right)_{2}\right]^{+}$, we estimate a rather low value value of $K_{5} \approx 31 / \mathrm{mol}$ for Eq. (5) with $\mathrm{P}(\mathrm{Et})_{3}$. For phosphines with still larger Tolman cone angles [38], such as tribenzyl, triphenyl or tricyclohexyl phosphine, no indication for a formation of bisphosphine complexes is apparent up to phosphine concentrations of $20 \mathrm{mM}$. Apparently, Eq. (5) responds very sensitively to increasing bulk of the two phosphine ligands which have to be placed in the narrow margin of the metallocene wedge.

The bis-trimethylphosphine complex $\left[\left(\mathrm{C}_{5} \mathrm{H}_{5}\right)_{2} \mathrm{Zr}\left(\mathrm{CH}_{3}\right)\left(\mathrm{PMe}_{3}\right)_{2}\right]^{+}$, however, is so stable that its partial formation is observable, by small but significant shifts of the $\mathrm{Zr}-\mathrm{CH}_{3}$ and $\mathrm{C}_{5} \mathrm{H}_{5}$ signals, in solutions of $\left(\mathrm{C}_{5} \mathrm{H}_{5}\right)_{2} \mathrm{Zr}\left(\mathrm{CH}_{3}\right)_{2}$ and $\mathrm{B}\left(\mathrm{C}_{6} \mathrm{~F}_{5}\right)_{3}$ even in the presence of less than one equivalent of $\mathrm{PMe}_{3}$, i.e., before formation of the monophosphine complex is complete. The monophosphine cation $\left(\mathrm{C}_{5} \mathrm{H}_{5}\right)_{2} \mathrm{Zr}$ $\left(\mathrm{CH}_{3}\right)\left(\mathrm{PMe}_{3}\right)^{+}$thus appears to undergo disproportionation according to Eq. (6).

$$
\begin{aligned}
2\left[\left(\mathrm{C}_{5} \mathrm{H}_{5}\right)_{2} \mathrm{Zr}\left(\mathrm{CH}_{3}\right)\left(\mathrm{PMe}_{3}\right)\right]^{+} \mathrm{A}^{-} & \\
\rightleftharpoons & {\left[\left(\mathrm{C}_{5} \mathrm{H}_{5}\right)_{2} \mathrm{Zr}\left(\mathrm{CH}_{3}\right)\left(\mathrm{PMe}_{3}\right)_{2}\right]^{+} \mathrm{A}^{-} } \\
& +\left[\left(\mathrm{C}_{5} \mathrm{H}_{5}\right)_{2} \mathrm{Zr}\left(\mathrm{CH}_{3}\right)^{+} \cdots \mathrm{A}^{-}\right]
\end{aligned}
$$

From the relative signal intensities for $\left[\left(\mathrm{C}_{5} \mathrm{H}_{5}\right)_{2} \mathrm{Zr}\left(\mathrm{CH}_{3}\right)^{+} \cdots\left(\mu-\mathrm{H}_{3} \mathrm{C}\right)-\mathrm{B}\left(\mathrm{C}_{6} \mathrm{~F}_{5}\right)_{3}^{-}\right]$ and for the sum of the two phosphine complexes and from an analysis of the signal shifts of the latter in the presence of 0.54 and 0.68 eqivalents of $\mathrm{PMe}_{3}$, we estimate a (dimensionless) value of $K_{6} \approx 0.4 \pm 0.1$ for the equilibrium constant of the disproportionation represented in Eq. (6).

This disproportionation reaction can be used as a test for the validity of the assumption that associated rather than solvent-separated ion pairs predominate in these reaction systems: If the latter were the case, the ensuing equilibrium Eq. (7) would lead — in distinction to Eq. (6) — to 
a dependence of the degree of reaction on the total zirconocene and borate concentrations. In the accessible concentration range between 1 and $2 \mathrm{mM}$ (which is limited by the formation of aggregated species at higher and by signal-tonoise problems at lower concentrations) the position of the averaged $\mathrm{Zr}-\mathrm{CH}_{3}$ signal of the two phosphine complexes $\left[\left(\mathrm{C}_{5} \mathrm{H}_{5}\right)_{2} \mathrm{Zr}\left(\mathrm{CH}_{3}\right)\right.$ $\left.\left(\mathrm{PMe}_{3}\right)\right]^{+}$and $\left[\left(\mathrm{C}_{5} \mathrm{H}_{5}\right)_{2} \mathrm{Zr}\left(\mathrm{CH}_{3}\right)\left(\mathrm{PMe}_{3}\right)_{2}\right]^{+}$ in solutions with a $\mathrm{P}: \mathrm{Zr}$ ratio of 0.7 remains unchanged at $-0.598 \mathrm{ppm}$, thus indicating an unchanged concentration ratio of these two species in accord with the presence of associated ion pairs as indicated in Eqs. (4)-(6).

$$
\begin{gathered}
2\left[\left(\mathrm{C}_{5} \mathrm{H}_{5}\right)_{2} \mathrm{Zr}\left(\mathrm{CH}_{3}\right)\left(\mathrm{PMe}_{3}\right)\right]^{+}+\mathrm{A}^{-} \\
\rightleftharpoons\left[\left(\mathrm{C}_{5} \mathrm{H}_{5}\right)_{2} \mathrm{Zr}\left(\mathrm{CH}_{3}\right)\left(\mathrm{PMe}_{3}\right)_{2}\right]^{+} \\
\quad+\left[\left(\mathrm{C}_{5} \mathrm{H}_{5}\right)_{2} \mathrm{Zr}\left(\mathrm{CH}_{3}\right)^{+} \cdots \mathrm{A}^{-}\right]
\end{gathered}
$$

Since $K_{6}$ is connected to $K_{4}$ and $K_{5}$ by the expression $K_{4}=K_{5} / K_{6}$, we can now estimate, from the values of $K_{5}$ and $K_{6}$ derived above, a value of $K_{4} \approx 16001 / \mathrm{mol}$ for the displacement of the anion $\mathrm{H}_{3} \mathrm{C}-\mathrm{B}\left(\mathrm{C}_{6} \mathrm{~F}_{5}\right)_{3}^{-}$by $\mathrm{PMe}_{3}$ from direct contact with the $\mathrm{Zr}$ center in the ion pair $\left[\left(\mathrm{C}_{5} \mathrm{H}_{5}\right)_{2} \mathrm{Zr}\left(\mathrm{CH}_{3}\right)^{+} \cdots\left(\mu-\mathrm{H}_{3} \mathrm{C}\right)-\mathrm{B}\left(\mathrm{C}_{6} \mathrm{~F}_{5}\right)_{3}^{-}\right]$ according to Eq. (4). For the other phosphines listed in Table 2 analogous data are not accessible, since their lower tendency to form the respective bisphosphine complexes does not allow observation of the disproportionation Eq. (6). Nevertheless, we assume that similarly high values of $K_{4}$ pertain also to the other phosphines studied here, since the contact ion pair $\left[\left(\mathrm{C}_{5} \mathrm{H}_{5}\right)_{2} \mathrm{Zr}\left(\mathrm{CH}_{3}\right)^{+} \cdots\left(\mu-\mathrm{H}_{3} \mathrm{C}\right)-\mathrm{B}\left(\mathrm{C}_{6} \mathrm{~F}_{5}\right)_{3}^{-}\right]$is undetectable in the presence of even the slightest excess of phosphine.

Finally, we have extended related studies also to two chiral ansa-zirconocenes, which give rise to stereoselective homogeneous catalysts for the isotactic polymerization of $\alpha$-olefins, i.e., to reaction systems containing $\mathrm{Me}_{2} \mathrm{Si}(\mathrm{ind})_{2} \mathrm{ZrMe}_{2}$ $[39,40]$ or $\mathrm{Me}_{2} \mathrm{Si}(2-\mathrm{Me}-\text { benz[e]ind })_{2} \mathrm{ZrMe}_{2}$ $[41,42]$ and $B\left(C_{6} F_{5}\right)_{3}$. In both cases, we ob-

\begin{tabular}{|c|c|c|c|c|c|}
\hline Complex & $\delta\left(\mathrm{C}_{5} \mathrm{H}_{x}\right)$ & & $\delta\left(\left(\mathrm{CH}_{3}\right)_{2} \mathrm{Si}\right)$ & $\delta\left(\mathrm{Zr}-\mathrm{CH}_{3}\right)$ & $\delta\left(\mathrm{PMe}_{3}\right)$ \\
\hline$\left(\mathrm{C}_{5} \mathrm{H}_{5}\right)_{2} \mathrm{ZrMe}\left(\mathrm{PMe}_{3}\right)^{+}$ & $5.50(10, \mathrm{~d}, 2.5 \mathrm{~Hz})$ & & & $-0.20(3, \mathrm{~s})^{\mathrm{b}}$ & \\
\hline \multirow[t]{2}{*}{$\left(\mathrm{C}_{5} \mathrm{H}_{5}\right)_{2} \mathrm{ZrMe}\left(\mathrm{PMe}_{3}\right)_{2}^{+}$} & $4.99(10, \mathrm{~s})^{\mathrm{b}}$ & & & $-1.44(3, \mathrm{~s})^{\mathrm{b}}$ & not resolved \\
\hline & $\mathrm{C}_{5} \mathrm{H}_{4}$ & $\mathrm{C}_{5} \mathrm{H}_{4}$ & & & \\
\hline \multirow{2}{*}{ 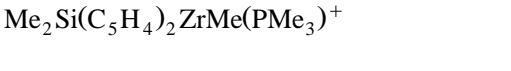 } & $4.87(2, \mathrm{pq})$ & $6.30(2, \mathrm{pq})$ & $0.16(3, \mathrm{~s})$ & $-0.20(3, \mathrm{~s})$ & $0.42(9, \mathrm{~d}, 8.3 \mathrm{~Hz})$ \\
\hline & $5.07(2, \mathrm{pq})$ & $6.44(2, \mathrm{pq})$ & $-0.04(3, \mathrm{~s})$ & & \\
\hline \multirow[t]{2}{*}{$\mathrm{Me}_{2} \mathrm{Si}\left(\mathrm{C}_{5} \mathrm{H}_{4}\right)_{2} \mathrm{ZrMe}\left(\mathrm{PMe}_{3}\right)_{2}^{+}$} & $5.55(4, \mathrm{pt})$ & $4.93(4, \mathrm{pt})$ & $0.15(6, s)$ & $-1.20(3, \mathrm{~s})$ & not resolved \\
\hline & Ind-H & $\alpha-\mathrm{C}_{5} \mathrm{H}_{2}$ & & & \\
\hline \multirow[t]{2}{*}{ rac $-\mathrm{Me}_{2} \mathrm{Si}(\text { ind })_{2} \mathrm{ZrMe}\left(\mathrm{PMe}_{3}\right)^{+}$} & not resolved & $5.15(1, \mathrm{~d}, 3 \mathrm{~Hz})$ & $0.59(3, \mathrm{~s})$ & $-1.14(3, \mathrm{~s})$ & $0.59(9, \mathrm{~d}, 11 \mathrm{~Hz})$ \\
\hline \multirow{2}{*}{\multicolumn{6}{|c|}{ rac $-\mathrm{Me}_{2} \mathrm{Si}(\text { ind })_{2} \mathrm{ZrMe}\left(\mathrm{PMe}_{3}\right)_{2}^{+}$}} \\
\hline & & & & & \\
\hline sym. & not resolved & not resolved & $0.22(6, s)$ & $-0.93(3, \mathrm{t})$ & not resolved \\
\hline \multirow[t]{2}{*}{ asym. } & not resolved & not resolved & $0.15(3, \mathrm{~s})$ & $-0.76(3, \mathrm{~s})$ & not resolved \\
\hline & & & $0.33(3, \mathrm{~s})$ & & not resolved \\
\hline \multirow{3}{*}{ rac- $\mathrm{Me}_{2} \mathrm{Si}(2-\mathrm{Me} \text {-benz }[\mathrm{e}] \mathrm{ind})_{2} \mathrm{ZrMe}\left(\mathrm{PMe}_{3}\right)^{+}$} & Benz-Ind-H & $2-\mathrm{CH}_{3}$ & & & \\
\hline & not resolved & $1.65(3, \mathrm{~s})$ & $0.69(3, \mathrm{~s})$ & $-1.15(3, \mathrm{~s})$ & $-0.03(9, \mathrm{~d}, 8.5 \mathrm{~Hz})$ \\
\hline & & $1.63(3, \mathrm{~s})$ & $0.62(3, \mathrm{~s})$ & & \\
\hline \multirow{2}{*}{$\begin{array}{l}\text { rac-Me }{ }_{2} \mathrm{Si}(2-\mathrm{Me}-\text { benz }[\mathrm{e}] \mathrm{ind})_{2} \mathrm{ZrMe}\left(\mathrm{PMe}_{3}\right)_{2}^{+} \\
\quad \text { sym. }\end{array}$} & & & & & \\
\hline & not resolved & $2.62(6, s)$ & not resolved & $\begin{array}{l}-1.10 \\
(3, t, 6, \mathrm{~Hz})\end{array}$ & not resolved \\
\hline \multirow[t]{2}{*}{ asym. } & not resolved & $2.35(3, \mathrm{~s})$ & not resolved & $-0.76(3, \mathrm{~s})$ & not resolved \\
\hline & & $2.17(3, \mathrm{~s})$ & & & \\
\hline
\end{tabular}

Table 2

${ }^{1} \mathrm{H}-\mathrm{NMR}$ signals for the mono- and bis-PMe $\mathrm{PM}_{3}$ complexes for various zirconocenes at $[\mathrm{Zr}]_{\mathrm{tot}} \leq 2 \mathrm{mM}^{\mathrm{a}}$ and $30^{\circ} \mathrm{C}$ in $\mathrm{C}_{6} \mathrm{D}_{6}$ solution $(250 \mathrm{MHz})$

${ }^{\mathrm{a}}$ At this concentration only the associated species with $\delta\left(\mathrm{H}_{3} \mathrm{C}-\mathrm{B}\right)=1.4 \mathrm{ppm}$ is observed.

${ }^{\mathrm{b}}$ Calculated limiting value.

${ }^{\mathrm{c}}$ Abbreviations for the multiplicity: $\mathrm{s}=$ singlet, $\mathrm{d}=$ doublet, $\mathrm{t}=$ triplet, $\mathrm{pt}=$ pseudotriplet, $\mathrm{pq}=$ pseudoquartet. 
serve, in dilute solutions with $[\mathrm{Zr}]_{\text {tot }}$ in the range of 1-2 $\mathrm{mM}$, the formation of a monophosphine complex of the associated type, i.e., with a $\mathrm{B}-\mathrm{CH}_{3}$ signal at $1.4 \mathrm{ppm}$ (Table 2).

In distinction to the reaction systems containing the $\mathrm{PMe}_{3}$-complexed ion pairs $\left[\left(\mathrm{C}_{5} \mathrm{H}_{5}\right)_{2}\right.$ $\left.\mathrm{Zr}\left(\mathrm{CH}_{3}\right)\left(\mathrm{PMe}_{3}\right)\right]^{+} \mathrm{H}_{3} \mathrm{C}-\mathrm{B}\left(\mathrm{C}_{6} \mathrm{~F}_{5}\right)_{3}^{-}$or $\left[\mathrm{Me}_{2}\right.$ $\left.\mathrm{Si}\left(\mathrm{C}_{5} \mathrm{H}_{5}\right)_{2} \mathrm{Zr}\left(\mathrm{CH}_{3}\right)\left(\mathrm{PMe}_{3}\right)\right]^{+} \mathrm{H}_{3} \mathrm{C}-\mathrm{B}\left(\mathrm{C}_{6} \mathrm{~F}_{5}\right)_{3}^{-}$ discussed above, $\left[\mathrm{Me}_{2} \mathrm{Si} \text { (ind }\right)_{2}-\mathrm{Zr}\left(\mathrm{CH}_{3}\right)$ $\left.\left(\mathrm{PMe}_{3}\right)\right]^{+} \mathrm{H}_{3} \mathrm{C}-\mathrm{B}\left(\mathrm{C}_{6} \mathrm{~F}_{5}\right)_{3}^{-}$and $\left[\mathrm{Me}_{2} \mathrm{Si}\right.$ (2-Me-benz [e] ind ) $\left.{ }_{2} \mathrm{Zr}\left(\mathrm{CH}_{3}\right)\left(\mathrm{PMe}_{3}\right)\right]^{+} \mathrm{H}_{3} \mathrm{C}-\mathrm{B}$ $\left(\mathrm{C}_{6} \mathrm{~F}_{5}\right)_{3}^{-}$do not show any detectable shifts of their NMR signals upon addition of excess $\mathrm{PMe}_{3}$, up to concentrations of ca. $20 \mathrm{mM}$. At $\mathrm{PMe}_{3}$ concentrations of 5-20 mM, we do however observe the appearance of two weak, sharp signal sets. These might be due to symmetric and asysmmetric bis- $\mathrm{PMe}_{3}$ complexes (Table 2 ), which interconvert only slowly with each other and with the monophosphine complex. Even if this assignment is correct, the equilibrium constants $K_{5}$ for the formation of these bisphosphine complexes are estimated to be smaller than $10 \mathrm{l} / \mathrm{mol}$ for the bis(indenyl) and bis(benzindenyl) zirconocenes. This greatly reduced tendency to form a bisphosphine complex is undoubtedly due again to steric effects: The coordination gaps of the $\mathrm{Me}_{2} \mathrm{Si}$-bridged bis(indenyl) and bis(2-Me-benz[e]indenyl) zirconocene complexes are significantly smaller than those of the $\left(\mathrm{C}_{5} \mathrm{H}_{5}\right)_{2} \mathrm{Zr}$ or $\mathrm{Me}_{2} \mathrm{Si}\left(\mathrm{C}_{5} \mathrm{H}_{4}\right)_{2} \mathrm{Zr}$ frameworks, in particular with respect to their lateral extension [43,44]: In $\mathrm{Me}_{2} \mathrm{Si}$ (ind) ${ }_{2} \mathrm{ZrCl}_{2}$ and $\mathrm{Me}_{2} \mathrm{Si}(2-\mathrm{Me}-$ benz[e]ind) ${ }_{2} \mathrm{ZrCl}_{2}$, the $\mathrm{CH}$ and $\mathrm{CH}_{3}$ units in $\alpha$-position to the $\mathrm{Me}_{2} \mathrm{Si}$ bridge protrude into the lateral section of the coordination gap and will thus impose serious thermodynamic and kinetic obstacles to the approach of a second phosphine ligand.

\section{Conclusions}

With regard to the coordination of an olefin, such as propene, to an alkyl zirconocene cation, the data discussed above lead to the following conclusions: In a non-polar solvent such as toluene, displacement of the anion from the $\mathrm{Zr}$ center by an olefin ligand will lead to the formation of associated ion pairs of the type $\left[\mathrm{Cp}_{2}^{x} \mathrm{Zr} \text {-alkyl(olefin) }\right]^{+} \mathrm{A}^{-}$; the geometrically non-descript outer-sphere association between cation and anion is likely to persist even at low zirconocene concentrations. Such an association with the anion, at least in the geometry derived from our density-functional calculations (Fig. 2), would not seem to impair the reactivity of the zirconocene cation: With a growing polymer chain in place of the Zr-bound methyl group and with an olefin in place of the $\mathrm{PMe}_{3}$ ligand, this species would meet all the requirements for an olefin-insertion reaction complex. The formation of such a reactive olefin complex should thus be described as in Eq. (8):

$$
\begin{aligned}
& {\left[\mathrm{Cp}_{2}^{x} \mathrm{Zr}(\text { alkyl })^{+} \cdots \mathrm{A}^{-}\right]+\text {olefin }} \\
& \quad \rightleftharpoons\left[\mathrm{Cp}_{2}^{x} \mathrm{Zr}(\text { alkyl })(\text { olefin })\right]^{+} \mathrm{A}^{-}
\end{aligned}
$$

The equilibrium constant $K_{8}$ for this reaction is undoubtedly much smaller than the value of $K_{4}$ obtained for the corresponding reaction with $\mathrm{PMe}_{3}$ : Due to its higher dipole momement and polarizabilty $\left(\mu=1.2 \mathrm{D}, \alpha=9.71 \AA^{-3}[45-\right.$ 47]) $\mathrm{PMe}_{3}$ will have a much higher affinity than an olefin such as propene ( $\mu=0.4 \mathrm{D}, \alpha=6.26$ $\AA^{-3}$ ) for the cationic, $d^{0}$-configurated $\mathrm{Zr}$ center. Reaction enthalpies for the exchange of a phosphine against an olefin ligand have so far been reported only for transition metals, such as zero-valent $\mathrm{Ni}, \mathrm{Pd}$ or Pt complexes [48,49], for which backdonation from filled metal d orbitals contributes substantially to the stability of the olefin complex. Comparable experimental data for olefin vs. phosphine exchange are not available for $\mathrm{d}^{0}$-configurated metal species such as the zirconocene methyl cation considered here.

$$
\begin{aligned}
& {\left[\mathrm{Cp}_{2} \mathrm{Zr}\left(\mathrm{CH}_{3}\right)\left(\mathrm{PMe}_{3}\right)\right]^{+}+\mathrm{C}_{3} \mathrm{H}_{6}} \\
& \quad \rightarrow\left[\mathrm{Cp}_{2} \mathrm{Zr}\left(\mathrm{CH}_{3}\right)\left(\mathrm{C}_{3} \mathrm{H}_{6}\right)\right]^{+}+\mathrm{PMe}_{3}
\end{aligned}
$$

In order to obtain at least an estimate for the reaction enthalpy of such a ligand exchange, we have studied Eq. (9) by density-functional cal- 
culations. This method has been successfully used to estimate reaction enthalpies for many types of organometallic reactions [50-52]. To test the reliability of this method for the type of reactions considered here, we have first determined the reaction enthalpy for the displacement of borate anion from the $\mathrm{Zr}$ center by $\mathrm{PMe}_{3}$, as represented in Eq. (4). Using the methods described in the Computational Part, we find a reaction enthalpy of $\Delta H_{4}=-41$ $\mathrm{kJ} / \mathrm{mol}$ for this reaction. This value is in satisfactory agreement with the value of $\Delta G_{4}^{0}=-18$ $\mathrm{kJ} / \mathrm{mol}$, derived from the experimentally determined value of $K_{4} \approx 16001 / \mathrm{mol}$ : These two figures would perfectly comply with the relation $\Delta G_{4}^{0}=\Delta H_{4}-T \cdot \Delta S_{4}^{0}$, if an entropy change of $\Delta S_{4}^{0} \approx-80 \pm 10 \mathrm{~J} /(\mathrm{mol} \mathrm{K})$ is associated with this reaction. An entropy change in this range is indeed very likely for Eq. (4), since an entropy loss in the order of $100 \mathrm{~J} /(\mathrm{mol} \mathrm{K})$, due to fixation of a $\mathrm{PMe}_{3}$ reactant, will be partly compensated by an entropy gain due to the increased mutual mobility of anion and cation in the resulting outer-sphere complex.

For the substitution of $\mathrm{PMe}_{3}$ by propene from a zirconocene methyl cation according to Eq. (9), our density-functional calculations yield a surprisingly high estimate of $\Delta H_{9}=+79$ $\mathrm{kJ} / \mathrm{mol}$. Neglecting the presence of outer-sphere ion pairs on both sides of Eq. (8) as well as the effects of $\beta$-agostic interactions of the alkyl chain with the $\mathrm{Zr}$ center [23,28,29,31], we obtain, from $\Delta H_{8} \approx \Delta H_{9}+\Delta H_{4}$, an estimate of $\Delta H_{8} \approx+44 \mathrm{~kJ} / \mathrm{mol}$ for the formation of an olefin-containing reaction complex according to Eq. (8). Since only a minor fraction of the zirconocene catalyst will be present under typical polymerization conditions in form of an olefin-containing reaction complex, $\Delta H_{8}$ must contribute directly to the overall activation energy $\Delta E^{\ddagger}$ of the polymerization catalysis. Comparison with experimentally determined values of $\Delta E^{\ddagger} \approx 30-54 \mathrm{~kJ} / \mathrm{mol}$ [17] indicates that our estimate for $\Delta H_{8}$ is probably too high.

Nevertheless, it is clear from the data discussed above that formation of the olefin-con- taining reaction complex constitutes a major contribution to $\Delta E^{\ddagger}$ and that there is still room for further efforts to develop catalyst systems where even higher activities ensue from a decrease in this energy increment.

A remarkable aspect of our results concerns the slow rate of interconversion between the contact ion pair $\left[\left(\mathrm{C}_{5} \mathrm{H}_{5}\right)_{2} \mathrm{Zr}\left(\mathrm{CH}_{3}\right)^{+} \cdots \mathrm{A}^{-}\right]$ and the phosphine complexes $\left[\left(\mathrm{C}_{5} \mathrm{H}_{5}\right)_{2} \mathrm{Zr}\left(\mathrm{CH}_{3}\right)\left(\mathrm{PR}_{3}\right)\right]^{+} \mathrm{A}^{-}$according to $\mathrm{Eq}$. (4): Exchange signals of rather low intensity indicate half-lives in the order of 5-10 s for this process. We assume that this ligand substitution proceeds by an associative mechanism, the transition state of which would require a direct cation-anion contact of the type $\left[\left(\mathrm{C}_{5} \mathrm{H}_{5}\right)_{2}\right.$ $\left.\mathrm{Zr}\left(\mathrm{CH}_{3}\right)\left(\mathrm{PR}_{3}\right)^{+} \ldots\left(\mu-\mathrm{CH}_{3}\right)-\mathrm{B}\left(\mathrm{C}_{6} \mathrm{~F}_{5}\right)_{3}\right]$, which appears to be sterically encumbered, as discussed above.

This line of reasoning would imply that similarly low interchange rates might pertain also for the corresponding reactions represented in Eq. (8), with olefin instead of phosphine ligands. If this is indeed the case, the half-live of an olefin complex of the type $\left[\mathrm{Cp}_{2}^{x}\right.$ $\mathrm{Zr}$ (alkyl)(olefin) $]^{+} \mathrm{A}^{-}$with respect to displacement of the olefin by the anion $\mathrm{A}^{-}$would be larger by several orders of magnitude than typical olefin-insertion half-lives, which can be estimated to be as short as several $\mathrm{ms}$ for more highly active zirconocene catalysts $[41,42]$. This raises the question as to the fate of the coordinatively unsaturated species arising from the olefin insertion, i.e. whether reconversion to a (presumably inert) contact ion pair or coordination of a new olefin ligand is the kinetically favored process. At any rate, the possibility that a relatively large number of consecutive olefin insertions might occur before an active zirconocene alkyl olefin cation is reconverted to a contact ion pair, would be highly relevant especially for the mode of operation of syndio-specific zirconocene catalysts [53-56], which is intimately dependent on the length of uninterrupted insertion sequences.

Formation of a bis(olefin) complex of the 
type $\left[\mathrm{Cp}_{2}^{x} \mathrm{Zr} \text { (alkyl)(olefin) }{ }_{2}\right]^{+} \mathrm{A}^{-}$, finally, appears rather unlikely: The formation of bisphosphine complexes was found to be critically dependent on the absence of steric bulk, both at the phosphine ligand and the zirconocene framework. An $\eta^{2}$-coordinated olefin, such as propene, will take up about as much space in the coordination sphere of a zirconocene cation as a $\mathrm{PMe}_{3}$ ligand [57]. This and the low affinity of olefins for the $\mathrm{d}^{0}$-configurated $\mathrm{Zr}$ center make it unlikely, especially for the sterically encumbered bis(indenyl) or bis(benz[e]indenyl) zirconocene catalysts, that the formation of a bis(olefin) complex causes the more than linear increase of catalyst activities with monomer concentration, e.g., an activity increase with $c$ (olefin) ${ }^{1.7}$ [17]. We are presently trying to clarify possible contributions to this non-linear concentration dependence, based on an analysis of the relative rates of individual elementary reaction steps in these complex catalyst systems.

\section{Experimental and computational part}

The zirconocene complex $\mathrm{Cp}_{2} \mathrm{Zr}\left(\mathrm{CH}_{3}\right)_{2}$ and the borane $\mathrm{B}\left(\mathrm{C}_{6} \mathrm{~F}_{5}\right)_{3}$ were synthesized according to literature methods [58-60]. Trityl tetrakis(perfluorophenyl)borate was purchased from Akzo Chemicals while the phosphines used $\left(\mathrm{PMe}_{3}, \mathrm{PEt}_{3}, \mathrm{PBu}_{3}, \mathrm{PMe}_{2} \mathrm{Ph}, \mathrm{PMePh}_{2}, \mathrm{PPh}_{3}\right.$, $\left.\mathrm{P}(p-\mathrm{OMe}-\mathrm{Ph})_{3}, \mathrm{PBn}_{3}, \mathrm{PCy}_{3}\right)$ were purchased from Aldrich.

All materials were kept and handled in a glovebox under $\mathrm{N}_{2}$. benzene- $d_{6}$ and toluene- $d_{8}$ solvents were purified by stirring over potassium metal, degassed, condensed onto a $4 \AA$ molecular sieve and then stored in a glovebox under exclusion of light. Stock solutions containing $0.04 \mathrm{~mol} / 1$ of each of the components $(0.4 \mathrm{~mol} / \mathrm{l}$ of the phosphines used at higher concentrations) were used to prepare the solutions for NMR measurements; these were transfered to rubber-stoppered $5 \mathrm{~mm}$ NMR tubes and measured on a Bruker WM-250 spectrometer. Relative concentrations of the species present in the equilibrium mixtures were determined by evaluating the integrals of their respective $\mathrm{C}_{5} \mathrm{H}_{5}$ signals.

For density-functional studies on complex geometries and reaction enthalpies, the functional of Vosko et al. [61] was used. For all calculations, program RIDFT [62] with the integration grid option 2 was used on an Iris Power-Challenge. The SVP valence basis set provided by this program was used for $\mathrm{C}, \mathrm{H}$ and $\mathrm{P}$ atoms; for $\mathrm{Zr}$, an effective core potential was used for the core electrons and a double- $\xi$ quality valence basis for the valence electrons. For the $J_{i j}$ Coulombic terms, the corresponding auxiliary basis sets were used for all atoms [62]. Nonlocal corrections for exchange and correlation were applied in the self-consistent procedure using the gradient-corrected functional according to Becke [63-65] and Lee et al. [66].

\section{Acknowledgements}

We thank Dr. Armin Geyer and Ms. Monika Cavegn for help with the measurement of twodimensional NMR spectra. Financial support of this work by BMBF, BASF AG, Fonds der Chemie and by funds of the University of Konstanz is gratefully acknowledged.

\section{References}

[1] W. Beck, K. Sünkel, Chem. Rev. 88 (1988) 1405.

[2] S.H. Strauss, Chem. Rev. 93 (1993) 927.

[3] P.G. Gassman, M.R. Callstrom, J. Am. Chem. Soc. 109 (1987) 7875.

[4] J.J. Eisch, S.I. Pombrik, G.X. Zheng, Organometallics 12 (1993) 3856.

[5] M. Bochmann, A.J. Jagger, J. Organomet. Chem. 424 (1992) C5.

[6] G.G. Hlatky, H.W. Turner, R.R. Eckman, J. Am. Chem. Soc 111 (1989) 2728.

[7] G.G. Hlatky, R.R. Eckman, H.W. Turner, Organometallics 11 (1992) 1413.

[8] X. Yang, C.L. Stern, T.J. Marks, Organometallics 10 (1991) 840.

[9] J.C.W. Chien, W.M. Tsai, M.D. Rausch, J. Am. Chem. Soc. 113 (1991) 8570 
[10a] J.A. Ewen, M.J. Elder, Can. Pat. Appl. 2,027,145.

[10b] J.A. Ewen, M.J. Elder, Chem. Abstr. 115 (1991) 136998g.

[11] J.A. Ewen, M.J. Elder, Makromol. Chem. Macromol. Symp. 66 (1993) 179.

[12] X. Yang, C.L. Stern, T.J. Marks, J. Am. Chem. Soc. 113 (1991) 3623.

[13] X. Yang, C.L. Stern, T.J. Marks, J. Am. Chem. Soc. 116 (1994) 10015.

[14] H. Sinn, W. Kaminsky, Adv. Organomet. Chem. 18 (1980) 99.

[15] C. Sishta, R.M. Hathorn, T.J. Marks, J. Am. Chem. Soc. 114 (1992) 1112.

[16] N. Herfert, G. Fink, Makromol. Chem. 193 (1992) 1359.

[17] S. Jüngling, R. Mülhaupt, U. Stehling, H.H. Brintzinger, D. Fischer, F. Langhauser, J. Polymer Science, Part A: Polymer Chem. 33 (1995) 1305.

[18] L. Resconi, A. Fait, F. Piemontesi, M. Colonnesi, H. Rychlicki, R. Zeigler, Macromolecules 28 (1995) 6667.

[19] C.P. Casey, S.L. Hallenbeck, D.W. Pollock, C.R. Landis, J. Am. Chem. Soc. 117 (1995) 9770.

[20] Z. Wu, R.F. Jordan, J.L. Petersen, J. Am. Chem. Soc. 117 (1995) 5867.

[21] R.F. Jordan, C.S. Bajgur, W.E. Dasher, A.L. Rheingold, Organometallics 6 (1987) 1041.

[22] R.F. Jordan, Adv. Organomet. Chem. 32 (1991) 325.

[23] Z. Guo, D.C. Swenson, R.F. Jordan, Organometallics 13 (1994) 1424.

[24] T. Haselwander, S. Beck, H.H. Brintzinger, in: G. Fink, R. Mülhaupt, H.H. Brintzinger (Eds.), Ziegler Catalysts, Springer-Verlag, Berlin, 1995, p. 181.

[25] S. Beck, M.H. Prosenc, H.H. Brintzinger, R. Goretzki, N. Herfert, G. Fink, J. Mol. Catal. A: Chemical 111 (1996) 167.

[26] J.E. Gordon, The Organic Chemistry of Electrolyte Solutions, Wiley, New York, 1975.

[27] M. Bochmann, S.J. Lancaster, M.B. Hursthouse, K.M. Abdul Malik, Organometallics 13 (1994) 2235.

[28] A.D. Horton, A.G. Orpen, Organometallics 10 (1991) 3910.

[29] A.D. Horton, A.G. Orpen, Organometallics 11 (1992) 8.

[30] R.F. Jordan, R.E. LaPointe, P.K. Bradley, N.C. Baenziger, Organometallics 8 (1989) 2892.

[31] R.F. Jordan, P.K. Bradley, N.C. Baenziger, R.E. LaPointe, J. Amer. Chem. Soc. 112 (1990) 1289.

[32] R.F. Jordan, R.E. La Pointe, C.S. Bajgur, S.F. Echols, R. Willett, J. Am. Chem. Soc. 109 (1987) 4111.

[33] Y.W. Alelyunas, N.C. Baenziger, P.K. Bradley, R.F. Jordan, Organometallics 13 (1994) 148.

[34] J.J.W. Eshuis, Y.Y. Tan, A. Meetsma, J.H. Teuben, J. Renkema, G.G. Evens, Organometallics 11 (1992) 362.

[35] D.M. Amorose, R.A. Lee, J.L. Petersen, Organometallics 10 (1991) 2191.

[36] A. Razavi, U. Thewalt, J. Organomet. Chem. 445 (1993) 111.

[37] H. Günther, NMR-Spektroskopie, Thieme-Verlag Stuttgart, 1992.

[38] C.A. Tolman, Chem. Rev. 77 (1977) 313.

[39] J.A. Ewen, L. Haspeslagh, M.J. Elder, J.L. Atwood, H.
Zhang, H.N. Cheng, in: W. Kaminsky, H. Sinn (Eds.), Transition Metals and Organometallics as Catalysts for Olefin Polymerization, Springer-Verlag, Berlin, 1988, p. 281.

[40] W.A. Herrmann, J. Rohrmann, E. Herdtweck, W. Spaleck, A. Winter, Angew. Chem. Int. Ed. Engl. 28 (1989) 1511.

[41] W. Spaleck, F. Küber, A. Winter, J. Rohrmann, B. Bachmann, M. Antberg, V. Dolle, E.F. Pauls, Organometallics 13 (1994) 954.

[42] U. Stehling, J. Diebold, R. Kirsten, W. Röll, H.H. Brintzinger, S. Jüngling, R. Mülhaupt, F. Langhauser, Organometallics 13 (1994) 964.

[43] K. Hortmann, H.H. Brintzinger, New J. Chem. 16 (1992) 51.

[44] S. Mansel, U. Rief, M.H. Prosenc, R. Kirsten, H.H. Brintzinger, J. Organomet. Chem. 512 (1996) 225.

[45] Landoldt-Börnstein, Zahlenwerte und Funktionen aus Physik, Chemie, Astronomie, Geophysik und Technik, vol. I, part 3, Springer-Verlag, Berlin, 1951, p. 511.

[46] Landoldt-Börnstein, Numerical Data and Functional Relationships in Science and Technology, New Series, Group II, vol. 4, Springer-Verlag, Berlin, 1967, p. 139.

[47] R.S. Armstrong, M.J. Aroney, R.J.W. Le Févre, R.K. Pierens, J.D. Saxby, C.J. Wilkins, J. Chem. Soc. A (1969) 2735.

[48] C.A. Tolman, W.C. Seidel, D.H. Gerlach, J. Am. Chem. Soc. 94 (1972) 2669.

[49] C.A. Tolman, W.C. Seidel, J. Am. Chem. Soc. 96 (1974) 2774.

[50] T.K. Woo, L. Fan, T. Ziegler, Organometallics 13 (1994) 2252.

[51] J.C.W. Lohrenz, T.K. Woo, T. Ziegler, J. Am. Chem. Soc. 117 (1995) 12793.

[52] P.E.M. Siegbahn, in: I. Prigogine, S.A. Rice (Eds.), Adv. Chem. Phys., Wiley, New York, 1996, p. 333.

[53] J.A. Ewen, R.L. Jones, A. Razavi, J.D. Ferrara, J. Am. Chem. Soc. 110 (1988) 6255.

[54] A. Razavi, J. Ferrara, J. Organomet. Chem. 435 (1992) 299.

[55] A. Razavi, U. Thewalt, J. Organomet. Chem. 445 (1993) 111.

[56] A. Razavi, J.L. Atwood, J. Am. Chem. Soc. 115 (1993) 7529.

[57] D.P. White, T.L. Brown, Inorg. Chem. 34 (1995) 2718.

[58] E. Samuel, M.D. Rausch, J. Am. Chem. Soc. 95 (1973) 6263.

[59] J.L.W. Pohlmann, F.E. Brinckman, G. Tesi, R.E. Donadio, Z. Naturforschg. 20b (1965) 1.

[60] J.L.W. Pohlmann, F.E. Brinckman, Z. Naturforschg. 20b (1965) 5.

[61] S.H. Vosko, M. Wilk, M. Nusair, Can. J. Phys. 58 (1980) 1200.

[62] K. Eichhorn, O. Treutler, H. Öhm, M. Häser, R. Ahlrichs, Chem. Phys. Lett. 242 (1995) 652.

[63] A.D. Becke, J. Chem. Phys. 84 (1986) 4524.

[64] A.D. Becke, J. Chem. Phys. 88 (1988) 1053.

[65] A.D. Becke, Phys. Rev. A 38 (1988) 3098.

[66] C. Lee, W. Yang, R.G. Parr, Phys. Rev. B 37 (1988) 785. 